\title{
CAPITAL COST AND CAPITAL STRUCTURE OF BUSINESSES IN THE MEAT INDUSTRY LISTED ON THE WARSAW STOCK EXCHANGE - A DISCUSSION ABOUT THE PROBLEM OF VALUATION
}

\author{
TOMASZ PAWLONKA \\ JUSTYNA AGNIESZKA FRANC-DABROWSKA
}

\begin{abstract}
The cost of capital is an important parameter in the assessment of efficient use of sources for business financing. This is also a measure enabling the indirect verification of the basic aim of the company's long-term business operations - an increase in value. So far, not fully transparent model of evaluating the cost of equity, both in theory and practice, has been developed. As a result, estimations concerning the cost of capital and value of companies are to a large extent subjective. The research - using the CAPM model together with its accepted parameters - proves the stability and precision of the applied methodology. Estimating the cost of capital is of special significance in companies from the Polish meat industry. These entities (in the years under investigation) were obliged to increase investment expenditures as a result of Poland's accession to the European Union and the necessity to adjust to western-European standards and further consolidation - both in the vertical and horizontal dimensions. Pro-developmental activities required changes in sources of finance and as a result - changes in capital structure. The dilemma concerning "safer" yet more expensive equity, or "cheaper" yet less stable foreign (interest) capital remains unsolved to this day.
\end{abstract}

Keywords: finance, cost of capital, agricultural companies.

JEL codes: G3, G21, Q1.

Dr Tomasz Pawlonka, Szkoła Główna Gospodarstwa Wiejskiego, Wydział Nauk Ekonomicznych, Katedra Finansów; ul. Nowoursynowska 166,02-787 Warszawa (tomasz_pawlonka@sggw.pl).

ORCID iD: 0000-0002-3463-7013.

Dr hab. Justyna Agnieszka Franc-Dąbrowska, Szkoła Główna Gospodarstwa Wiejskiego, Wydział Nauk

Ekonomicznych, Katedra Finansów; ul. Nowoursynowska 166, 02-787 Warszawa

(justyna_franc_dabrowska@sggw.pl). ORCID iD:0000-0002-5881-0343. 


\section{Introduction}

The years between 2001 and 2017 were especially significant for the meat industry. This was a very dynamic decade for the sector, characterized by great change. Between 2001 and 2006 the fundamental aim for most meat enterprises was to meet the restrictive EU sanitary and quality requirements and adjust production to Western European standards. At the beginning of the $21^{\text {st }}$ century, the meat sector in Poland was given little chance of achieving this task (in 2001 only 3.05\% of meat industry businesses operating in Poland fulfilled these EU requirements). However, these standards were achieved due to the efficient use of aid resources and expenditures for investment and modernization (by 2006 approx. 40\% of meat industry enterprises had obtained authorization for the EU market trading, 98\% of which were large and medium-sized entities). Huge investment outlays also led to many significant changes in the structure of liabilities for this group of enterprises. Entities from the meat sector were faced with the dilemma of choosing between cheaper external sources of finance, or increasing their equity, which would be a more stable albeit more expensive source (Obidzińska, 2008). The consequences of the decisions made within this scope can still be felt today.

Despite many positive forecasts for the meat industry at the beginning of the last decade, many (of the then diagnosed) problems remain unsolved. In hindsight, it occurs that low profitability and efficiency require further lowering of costs and intensifying consolidation processes. As a result, extra investments in the meat business are required with the purpose of lowering operational costs and further increasing the quality of products (Rawa, 2009). Moreover, finding savings in the financial activity of enterprises is not without significance. The (as near as possible) optimal capital structure seems to be an appropriate aim. This involves identifying dispensable external financing and indicating unused developmental potential associated with an inappropriate use of financial leverage, whilst limiting the cost of equity.

The article proceeds to discuss and review capital cost and capital structure of businesses in the meat industry listed on the Warsaw Stock Exchange. Section 1 deals with aim of the research, methodology. Section 2 is based on a theoretical background: capital cost - valuation dilemma. Section 3 illustrates the meat industry in Poland - characteristics and identification of the research problem. Section 4 presents our research findings. Section 5 presents the general conclusions and limitations of the study.

\section{Aim of the research, methodology}

The main aim of the research was to identify the weighted average cost of capital of meat sector enterprises listed on the Warsaw Stock Exchange between 2001 and 2017. The following specific objectives were achieved (within the scope of the main aim):

- A diagnosis of the usefulness of long-term returns on investment from the base index and using annual rates of return from the index - a subjective assessment;

- Establishing the cost of (owner) equity in investigated enterprises so that they result from the $\beta$ parameter; 
- Estimation of the $\beta$ for investigated enterprises so that it corresponds to the calculation methodology and accepted risk-free returns and long-term rates of return from the base index;

- Identifying the dependency between capital structure and the cost of foreign capital.

To achieve the main aim and specific objectives, the following research hypothesis was formulated:

H 1. Cost of equity in meat sector enterprises is dependent on the $\beta$ coefficient;

H 2. Growth of invested foreign capital cost corresponds to the growth of interest (owned) in the structure of liabilities.

Amongst commonly used equity valuation models the Capital Asset Pricing Model (CAPM) was selected. The choice of this model of capital asset valuation was determined by its practical appreciation as well as it being the most popular model of (owner) equity valuation. The choice of the CAPM model enables relative data transparency. It relys on generally accessible data which facilitates and, in many cases, makes it possible to evaluate the cost of equity (Bartholdy and Peare, 2003). Research conducted by PricewaterhouseCoopers reveals that nearly $70 \%$ of practices use the CAPM model to evaluate the cost of equity, which is evidence of its acknowledgment (Byrka-Kita, 2008). The CAPM model used in the study is the first simple version. The authors are aware of the direction of the inclusion of additional risk factors, which are offered by improved versions of the capital asset pricing model (e.g. the modification of Fama and French). Identification of the cost of equity in the conditions of the Polish economy, in which the young capital market is not the main part of the financial market, is difficult due to structural limitations. The main limitations include the short age of the Polish Stock Exchange. According to Pereiro's research, because of volatility of stock prices in emerging markets the estimation of the beta parameter and its application to the valuation of the cost of equity capital using the CAPM model raises many doubts (Pereiro, 2010). The identification of the relationship between the beta parameter and the cost of equity, allows for assessment of the scale of impact of individual CAPM parameters on the cost of equity. This research is also a tool for identifying the suitability of selecting model parameters, so that, for example, the market risk premium and the risk-free rate do not limit the impact of the company's systemic risk on the final calculation of the cost of equity volatility of individual securities and a limited number of companies operating on the stock exchange. As a result, the use of multi-indicator models, based on divisions of the research sample and the identification of risk factors such as SMB and HML (the three-factor Fama and French model), seems impossible to implement in the perspective of the limited sample size (9 companies). Nevertheless, the authors agree on the necessity to enrich the CAPM model with additional risk factors, mainly resulting from the industry characteristics. Other, less popular models used to evaluate the cost of capital include: 
- The Gordon Model - limited use of this model is associated with a lack of continuity in paying out company dividends (Ross, Westerfield and Jordan, 2008), especially visible in companies belonging to the meat sector in Poland;

- APT model - limiting the arbitrary price theory model is based on difficulties in identifying groups of universal factors for all assets alongside additional considerations of variability at times of risk attributed to particular groups of assets (Kolb, 1995).

Despite a number of listed advantages of the CAPM model, several limitations can be found. One of the most basic reservations concerns a lack of unequivocal procedures for the selection of model components such as risk-free returns, underlying rate of return time horizons, discussion about the methodology for determining the $\beta$ parameter, or the very debate about the credibility of the $\beta$ coefficient as a measure of risk associated with investing in assets of a given enterprise (Fierla, 2008).

Comparing the advantages and disadvantages of the CAPM model shows that despite an outline of the rules for selecting particular parameters, its construction is to a large extent of an expert character and the credibility of the findings depends on the expertise and experience of researchers and their tendency to "market-orient" the valuation (Laderman, 1988). One must also realize that the CAPM model, in the same way as other known, available and applied equity valuation models gives approximate results (K. Jajuga and T. Jajuga, 1994).

The research covered all meat sector enterprises listed on the Warsaw Stock Exchange in 2001-2017 for at least 2 years. This condition was met by: Sokołów S.A. (2001-2006), Drosed S.A. (2001-2004), Indykpol S.A. (2001-2017), PKM Duda S.A (2003-2016), Pamapol S.A. (2006-2017), Drop S.A. (2007-2017), Gobarto S.A. (2003-2017), ZM Henryk Kania S.A. (2009-2017) and Tarczyński S.A. (2013-2017). Stock market quotation of companies came from the stooq.pl website, which offers free access to stock market data and their export to files enabling further editing.

The CAPM model used in the research takes on the form of Security Market Line (SML) presented in formula 1 (Duliniec, 2001):

$$
R=R_{f}+\beta\left(R_{m}-R_{f}\right)
$$

where:

$R$ - expected rate of return (cost of equity),

$R_{f}$ - risk-free rate,

$R_{m}-$ (underlying) rate of return from market,

$\beta-$ measurement of risk associated with investing in a given security.

The first stage of constructing the CAPM model was the choice of an instrument with a rate of return identical to risk-free ones. Fifty-two-week treasury bonds are commonly applied in scientific literature, as well as long-term government bonds (Pluta, 2009). The research used 10-year treasury bonds with a risk-free rate of 
return (see Franc, 2003). This approach is more widely acknowledged in subject literature, though certain flaws in the concept of risk-free rates of return are known, including long-term ones (Patena, 2011). The choice is justified for a number of reasons (Grzywacz, 2012):

- Corporate equity is characterized by a long-time horizon (which is a recommended period of analysis) and is the most stable component of liabilities. Investment in the capital of a given company (especially in the case of retained profit) is usually oriented towards its growth in value, development and cashing in on a satisfactory rate of return for its owners. This indicates a necessity for analyzing the cost of the company over a long period of time. The risk-free return should also be of a long-term perspective.

- The yield from 10-year treasury bonds includes many corrections which are not included in 52-week treasury bonds. The most important is inflation.

- The yield from 10-year bonds is better adjusted to discounted cash flow, and a 10-year period seems appropriate for share capital.

- The application of yield from 10-year bonds, as a measure of risk-free rates, limits the influence of short-term fluctuations of risk-free interest rates, which is a rational, market-oriented and logical approach. A rapid change of risk-free rates is unlikely. High standard aberrations would indicate additional risk associated with the variability of "safe" rates of return, which would then require additional, subjective corrections.

The next step in the construction of the CAPM model was to establish market rates of return. The WIG-SPOZYWCZY index was chosen in the light of research into the meat sector. This index has been listed on the Warsaw Stock Exchange since January 5, 1998, which hinders precise calculations. An effect of focusing the research towards a long-term horizon and consistent use of long-term measures should be a 10-year period of analysis of underlying return. For example, in 2010 the years encompassing "WIG-SPOZYWCZY index - rate of return" were 2001-2010, a 10-year time horizon. However, in 2001-2006 this condition was not achieved. In this case, the researchers chose the maximum possible time period (to evaluate the rate of return from the index). The research used daily fluctuations of underlying index prices from 1998-2017. Another limitation in the research was also high standard aberrations in rates of return, which is characteristic of fledgling capital markets (such as Poland) (Duliniec, 2001). Due to negative rates of return from the index in given years, it is impossible to apply the harmonic mean as a method of averaging the results. According to Damodaran (1994), the research used arithmetical average as a method of establishing annual underlying rates of return. In this case, it was justified not by time-horizon but by instability, changeability, and "young age" of the Polish stock exchange.

The measure of systemic risk in the CAPM model is the $\beta$ coefficient. The studies of Sharpe and Cooper (1972); Douglas (1968); Black, Jensen and Scholes (1972), Fama and MacBeth (1973) (see Da, Guo and Jagannathan, 2012) confirm the validity of the CAPM model and its compatibility with reality, and indicate the $\beta$ coefficient as an appropriate measure of undiversified risk. Although, these 
studies were questioned and modified many times, no better measure or model has been found to explain the dependency between expected rate of return from invested capital and associated risk (Byrka-Kita, 2008). One of the biggest difficulties in constructing the CAPM model is establishing the time horizon when estimating the $\beta$ parameter (Duliniec, 2001). The use of the $\beta$ parameter in Poland's economic environment is sometimes questioned. This is because of its high changeability over time (lack of stability) which is confirmed by some studies based on Chow's test (Kuziak, 1999). According to studies conducted by Osińska and Stempinska (2003), lengthening the time horizon to measure the $\beta$ indicator, enables its stabilization. But, applying too long a horizon, tarnishes the current condition of the company with data from the distant past. Though no scheme regarding the depth of retrospection has been worked out for the $\beta$ parameter, academic literature most frequently uses 12- to 60-month periods for analysis. But 12-month time horizons are often criticized, especially due to their lack of stability (Byrka-Kita, 2008). The estimation of the $\beta$ parameter is conducted on the basis of two methods (Osińska and Stempinska, 2003):

- The recursive method, where the first attempt was composed of 48-month elements (depending on data availability) with each next attempt increased by another 12 months, not exceeding 120 months in total.

$\left(I_{n R E C}=\overline{\ln -9, \ln -8, \ldots, \ln }\right)$

- The moving window method, with a 36- and 48-month time period.

$$
\left(I_{n 48}=\overline{\ln -3, \ln -2, \ldots, \ln }\right),\left(I_{n 36}=\overline{\ln -2, \ln -1, \ldots, \ln }\right)
$$

On account of the consistent analysis of capital cost in the investigated companies from a long-term perspective, a 48-month period was applied for the estimation of the $\beta$ parameter, based on daily price fluctuations of the analysed papers and WIG-SPOZYWCZY index. This approach constitutes a rational compromise between standards accepted by institutes involved in providing commercial data about capital markets. Most of these companies, for example Morningstar Ibbotson, Value Line or Standard \& Poor, basing on the studies of Black et al. (1972), use a 60-month time perspective for the $\beta$ parameter estimation. Bloomberg, which uses a 24-month time horizon, is an exception (Patena, 2011). A 48-month period of retrospection used to estimate the $\beta$ parameter ensures relative stability of the indicator over time and does not warp the assessment of current company conditions due to the past data.

Financial statements published in the EMIS Intelligence from the years between 2001 and 2017 were used to establish the cost of foreign capital for the companies under research. The cost of foreign capital was established as the relation of financial costs (profit and loss statement) to the average rate of interest liabilities (average from year $n$ and year $n$-1). Establishing foreign capital cost as a relation of interest expenses (from the cash flow statement) to interest liabilities is also accepted in scientific literature (Łukasik, 1998). 


\section{Theoretical background: capital cost - valuation dilemma}

The issue concerning capital structure and its cost is just as fascinating as it is difficult to unequivocally evaluate. Academic discussions concerning the optimization (quasi-optimization) of capital structure and cost have been ongoing for decades. They first appeared in the 1960s in the works of Modigliani and Miller (1958; 1963) and were continued by many renowned economists (such as Stiglitz 1974; Myers and Majluf, 1984; Masulis, 1988; Brown, Lajbcygier and Wong, 2012). Heated discussions also took place during the $40^{\text {th }}$ Anuual Meeting of the European Finance Association, which featured presentation of the opinions of Chen, Harford and Kamara (2013) and Fairhurst (2013). The issue of capital structure optimization remains "enigmatic" in the world of finances. So far, no solution has been found which would allow entrepreneurs to practically optimize their capital structure. Varying opinions can already be found at a theoretical level (see Lagerkvist, 1999; Acharya, Shin and Yorulmazer, 2013). Many other current factors influencing the financial condition of enterprises additionally complicate decisions related to capital and their resulting consequences (see Hüttel, Mußhoff and Odening, 2010; Boubakri, Guedhami, Mishra and Saffar, 2012; Arouri, Rault, A. Sova, R. Sova and Teulon, 2013).

For many years, discussions concerning the necessity to correct the method of calculating the cost of equity have been pending (see Franc-Dąbrowska, 2009). This is a basic problem in the procedure of estimating "real effects" for the business. Financial results (in their classic form) do not encompass the cost of (owner) equity, thus failing to give information about the real benefits resulting from the use of this capital. This is a particularly important problem for agricultural enterprises. In such entities, attempts have also been made to estimate and assess the cost of (owner) equity and its relation to capital structure. Moreover, the results of these attempted estimations, made for agricultural enterprises (see Franc, 2003; Kulawik, 1998), have been unsatisfactory. In many cases businesses were unable to pay for this factor of production.

Agricultural enterprises are particularly sensitive to meteorological changes (especially plant producers) and natural growth processes in both plants and animals. Therefore, the associated risks undertaken by such businesses are relatively high and require consideration in (the cost of equity) financial statements. Agricultural enterprises are also highly equipped with fixed assets, which to a large (financial) extent are part of (owner) equity. Thus, part of the (owner) equity becomes "tied up" and cannot be "released" quickly or (in some cases) at all (if, for example, the entrepreneur wishes to resign from running the business).

Another interesting dependency characterizing agricultural enterprises is that entrepreneurs running such businesses on their own account (and risk) experience better effects (of management) - as stated in the findings of Franc-Dąbrowska (2010). Similar observations are recorded in data analysis of "Ranking 300". Their results show that the highest rate of return from sales is found amongst entrepreneurs who purchase the majority of their estate, next come enterprises whose 
estate is mainly leased, followed by single-companies of the Agricultural Property Agency of the State Treasury. These groups of enterprises can be categorized in the same way, using criteria from the value creation index (Ranking ..., 2012). The results presented by the "Ranking 300" team confirm those in previously mentioned studies. Here, emphasis should also be placed on the problem of evaluating the cost of (owner) equity, as a rare resource, especially in times of economic crisis (see Boratyńska, 2009).

When considering the problematic issues of valuation of (owner) equity cost particularly with reference to agricultural enterprises - Kulawik's (ed., 2008) proposal should be highlighted. The author introduced a modification of the capital asset valuation model and corrected the $\beta$ coefficient (a measure of systematic risk resulting from the volatility of the company's share price). Kulawik acknowledged individual risk for agricultural enterprises, (differentiating it) on the basis of operational activity. This proposal should be considered important, both from a theoretical and practical perspective. Another approach, based on research of the opinions of those managing agricultural enterprises were presented by Franc-Dąbrowska and Kobus (2012), who stated that only some entrepreneurs see the need to evaluate the cost of (owner) equity, and if necessary, it is calculated on the basis of deposit account interest rates (as an alternative source of obtaining income).

An interesting perspective was presented by Boratyńska (2009), who focused on the important issue of the cost of company bankruptcy. The author's findings show that the cost of bankruptcy proceedings is indirectly incurred by both the creditor and debtor. As a result, the creditor's claim cannot be fully met, whereas the debtors liabilities can rise. This is another issue worth taking into consideration with regard to the cost of invested capital and the targeted capital structure. In turn, Zawadzka's (2009) findings proved that the significance of short-term liabilities is variable and, in Poland, is dependent on the sector. Similarly, Boratyńska (2012), identified bankruptcy models for enterprises of the (food) meat sector.

Such perspectives in research show the need for further analysis of the capital structure and cost, with particular focus on the specifics of the meat sector.

Why is establishing the cost of (owner) equity so important? Due to the fact that it constitutes a necessity and basis for making decisions concerning the sources of business financing, thus shaping the capital structure (Miller, 2009) ${ }^{1}$. It further carries consequences when making decisions about where to designate profit - be that to inject (owner) equity or, for example, pay out dividends. Capital structure optimization models are insufficient for agricultural enterprises. This is because these companies function in many various legal forms, at different levels of proprietorship, and with varied types of production (of different dependencies on agroclimatic conditions and biological features of plants and animals). This is a particular group of enterprises, enabling food security for its people.

Moreover, because of historical determinants - farmers constitute a large employment and residential group in Poland. Due to this group's specificity, it is not

\footnotetext{
${ }^{1}$ See e.g. Miller's (2009) discussions about modified WACC.
} 
always possible to transfer generally available solutions. It is, however, possible (by using the findings of researchers) to acknowledge the specific conditions of this group of entities and thus for authors to attempt to evaluate the cost of (owner) capital and its relation to capital structure. Moreover, in our opinion a modification of the proposed methods, rather than a proposal of new ones, should be made. This stems from the fact that a balance for optimal capital structure has been proposed and in its general form should not be questioned. But then, it is not always suitable for the researched entities and thus requires improvement. We also call for agricultural sector entities not to be excluded from the domain of scientific considerations. The very scale of their activity as well as the owners' need for recommendations are reasons enough to include agricultural enterprises into the scope of scientific interest and debate. This is despite a current deficit (within its ranks) of teams specializing in capital structure management. Nonetheless, agriculture's role in economic sciences has always been a starting point for all other sectors.

Tables 1 and 2 present selected data concerning the beta level. These data show the results for six of the largest US food processing entities whose total market share was 94\% (International Markets Bureau, 2012). A relatively large variance in the beta parameters over time was observed for respective companies and between them. If, however, the average size is taken into consideration, the beta values move towards levels oscillating at 1 , which is accepted as characteristic for the agricultural sector (every person needs food to survive).

Table 1

The beta parameters for 6 of the largest US food processing companies

\begin{tabular}{|c|c|c|c|c|c|c|c|c|c|c|c|}
\hline \multirow{2}{*}{ Company } & \multirow{2}{*}{$\begin{array}{c}\text { Market } \\
\text { share } \\
2011 \\
\end{array}$} & \multicolumn{10}{|c|}{ The beta parameters - window method - 36 months } \\
\hline & & 2001 & 2002 & 2003 & 2004 & 2005 & 2006 & 2007 & 2008 & 2009 & 2010 \\
\hline Tyson Foods & $38 \%$ & 0.80 & 0.30 & 0.65 & 0.55 & 0.87 & 0.56 & 0.43 & 1.45 & 1.26 & 1.23 \\
\hline JBS S.A. & $22 \%$ & $\mathrm{X}$ & $\mathrm{X}$ & $X$ & $X$ & $\mathrm{X}$ & $X$ & $X$ & $\mathrm{X}$ & $X$ & $\mathrm{X}$ \\
\hline $\begin{array}{l}\text { Smithfield } \\
\text { Foods Inc. }\end{array}$ & $15 \%$ & 1.05 & 0.90 & 0.92 & 0.75 & 0.90 & 0.03 & 0.43 & 1.82 & 2.09 & 1.93 \\
\hline $\begin{array}{l}\text { Pilgrim's Pride } \\
\text { Corporation }\end{array}$ & $13 \%$ & 0.70 & 0.28 & 0.95 & 1.07 & 0.54 & 1.00 & 0.49 & 0.79 & 0.81 & 0.92 \\
\hline $\begin{array}{l}\text { Sanderson } \\
\text { Farms, Inc. }\end{array}$ & $3 \%$ & 0.70 & 1.15 & 1.12 & 1.49 & 1.53 & 1.91 & 1.19 & 0.83 & 0.69 & 0.54 \\
\hline Hormel Foods & $3 \%$ & 0.50 & 0.13 & 0.43 & 0.48 & 0.37 & 0.08 & 0.12 & 0.62 & 0.44 & 0.45 \\
\hline Average & $\begin{array}{c}\text { TOTAL }= \\
94 \%\end{array}$ & 0.75 & 0.55 & 0.81 & 0.87 & 0.84 & 0.72 & 0.53 & 1.10 & 1.06 & 1.01 \\
\hline
\end{tabular}

Source: own calculations based on data from The New Yourk Times - Business Day Markets and Google Finance - NASDAQ.

Similar observations are found in the data presented in Table 2. By analysing recursive beta for six of the largest US market enterprises, quite a significant variation of the beta levels is observed. However, the average value is slightly 
below level 1. Moreover, the largest entities of the US market are characterized by a higher recursive beta value (on average) in relation to the average value of the entire food processing sector.

Table 2

Recursive beta for selected enterprises

\begin{tabular}{lc}
\hline \multicolumn{1}{c}{ Company } & Recursive beta \\
\hline Tyson Foods & 0.41 \\
JBS S.A. & 1.12 \\
Smithfield Foods Inc. & 1.06 \\
Pilgrim's Pride Corporation & 0.92 \\
Sanderson Farms, Inc. & 1.13 \\
Hormel Foods & 0.66 \\
Whole food processing sector & 0.61 \\
\hline
\end{tabular}

Source: own calculations based on data from the The New Yourk Times - Business Day Markets and Yahoo! Finance - TSN, www.reuters.com and www.nasdaq.com.

\section{Meat industry in Poland - characteristics and identification of the research problem}

The successful adjustment of the Polish meat industry enterprises to Western European standards failed to solve many or even most of the problems of the sector (Wieczorkiewicz, 2008). These businesses still remain rather unprofitable in comparison to the average for the food industry in general. Low profitability and thus a limited capacity for profit margins, gives the meat sector little significance as a source of increasing equity (Kalwasińska, 2011). A significant barrier for the development of the meat sector is its high fragmentation (in 2009, seven of the largest meat factories in Poland had barely a 20\% share in the market) (Kowalski, 2011). Another problem is high dependency on the supply and prices of raw meat. A solution seems to be vertical and horizontal integration. This currently involves the costly takeover of bankrupt or failing meat plants. A role model worth emulating may be, for example, the Danish meat market.

As a consequence of the lack of vertical integration in the Polish enterprises the supply of raw meat is fragmented, which leads to differences in meat sensory features ${ }^{2}$. This causes difficulties in the production of homogenous, ready-made products. Thus, Polish meat products are not competitive in comparison to Danish products on restrictive markets such as Japan or Russia (Polish meat on this market is also less competitive than meat imported from the US) (Obidzińska, 2008). Moreover, though the number of companies (in the meat sector) dropped from

\footnotetext{
${ }^{2}$ As research shows, the feeding and grazing system is fundamental to the sensory characteristics of meat (Sadowska, Rakowska, Dybkowska and Świąder, 2016; Augustyńska and Sokołowicz, 2014; Łącka, 2012).
} 
6 thousand in 2000 to 1.2 thousand in 2010, significant fragmentation is still a barrier to development (Knapp-Stefaniuk, 2010). According to data from 2017, there were about 1250 enterprises from the meat industry in Poland, of which 170 were poultry meat processors. At the same time, $40 \%$ of all enterprises in the meat industry were small enterprises (mainly family enterprises) in which employment did not exceed 9 employees (Rawa, 2017).

The meat sector in Poland is characterized by an obvious mismatch of assets and liabilities. As a consequence, due to a long deadline for the collection of payments and short deadline for paying off current liabilities, meat sector companies are faced with a cash flow gap and thus a requirement for additional sources of financing (Sroka, 2010). This pattern was especially visible during the financial crisis which, although failed to affect Polish entrepreneurs to such an extent as their Western European competitors, caused serious difficulties in settling payments on time for foreign investors (especially Ukrainian). As a result, an additional demand for capital was observed amongst Polish businesses in the Polish meat industry (Drewnowska, 2010).

Polish consumer choices, when selecting meat products, are governed by quality and price. As a result of a slowdown in economic growth, an effect of the financial crisis, a lower demand for meat was observed (Górnicka, 2005). A change of culinary preference also played its part. A growing demand for vegetarian and vegan food products, associated with the so-called healthy eating, was noticed. Despite this, in 2002-2017, as a result of economic growth, decreasing unemployment and an increase in the wealth of the Polish society, these was over $9 \%$ increase in meat consumption. However, the demand for meat remained sensitive to changes in its prices and depends on the amount of income of consumers (Milan, 2017).

Another significant difficulty for Polish businesses of the meat industry was the strengthening of the Polish Zloty (PLN) in relation to foreign currencies. In 2008-2010 , this made Polish meat products significantly less competitive on foreign markets. Moreover, during this time, Polish enterprises also became less competitive, in comparison to their foreign competitors on the domestic market (Cukiernik, 2008). In addition, the difficulties of the meat industry are aggravated by the ASF virus, which in 2014-2017 led to the liquidation of 3.7 thousand farms involved in the production of raw material. The challenge that the meat industry will face in Poland from the beginning of 2019 will be the ban on the use of GMO soy protein in feed, which accounted for around 20\% of feed demand in Poland (Milan, 2017).

\section{Research findings}

The moving window method (MW48) and the recursive method (REK) were used to estimate the $\beta$ parameters in companies from the meat sector. The results are presented in Table 3 . 


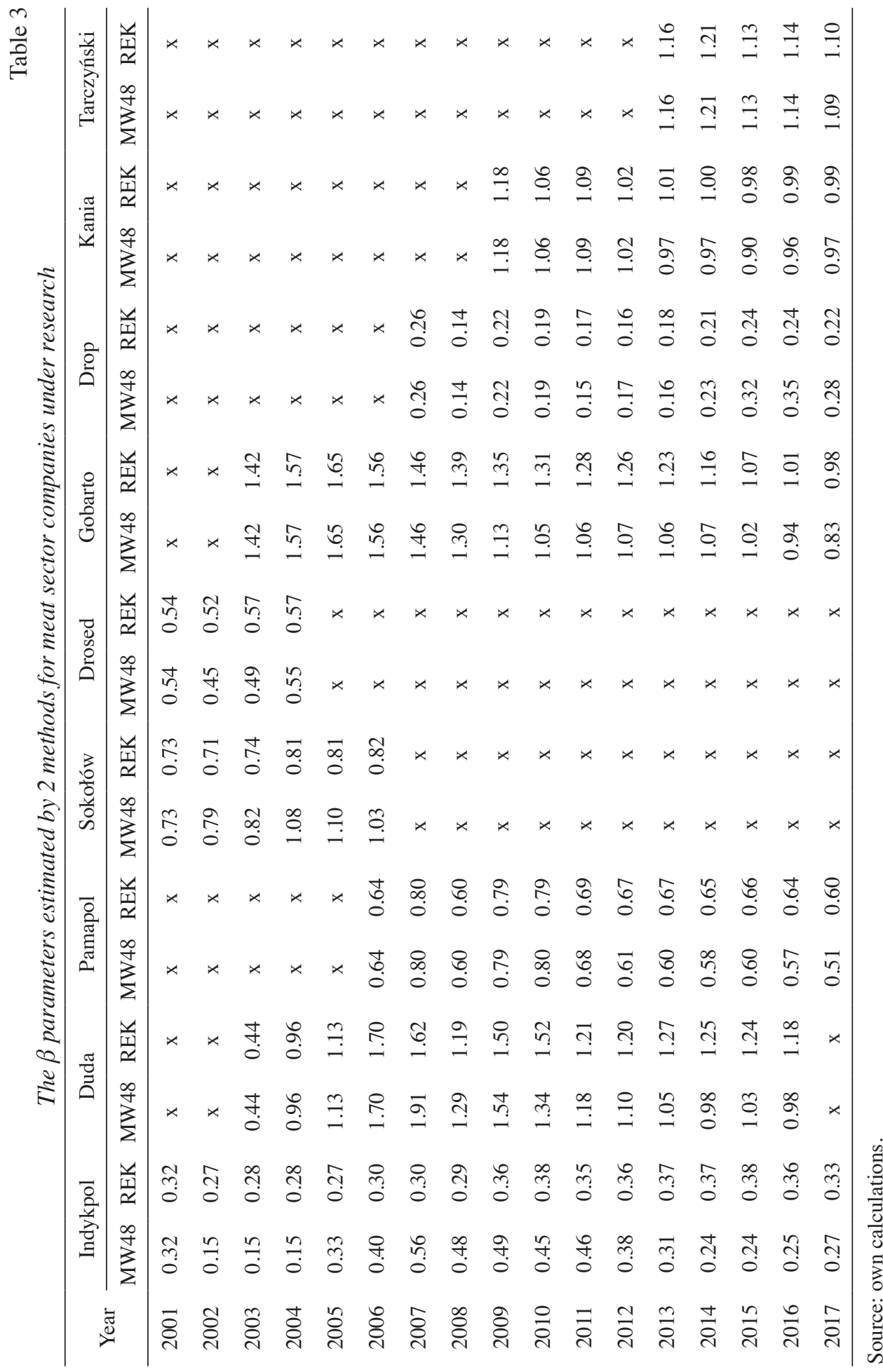


The application of the recursive method gives higher results of stability to the $\beta$ parameters in all of the investigated companies. This result is in line with expectations, however, the final result may not be accepted as credible on account of the method used. The moving windows method with a 48-month time period made the research more realistic and separated the assessment of current company conditions from the past data. The estimation of the $\beta$ parameters with this method showed greater variation over time. There was (on average) an $11.16 \%$ difference to the $\beta$ parameter values estimated by way of the recursive method. The application of the moving windows method (with a 36-month period) is shown for the Indykpol S.A. Company in Figure 1.

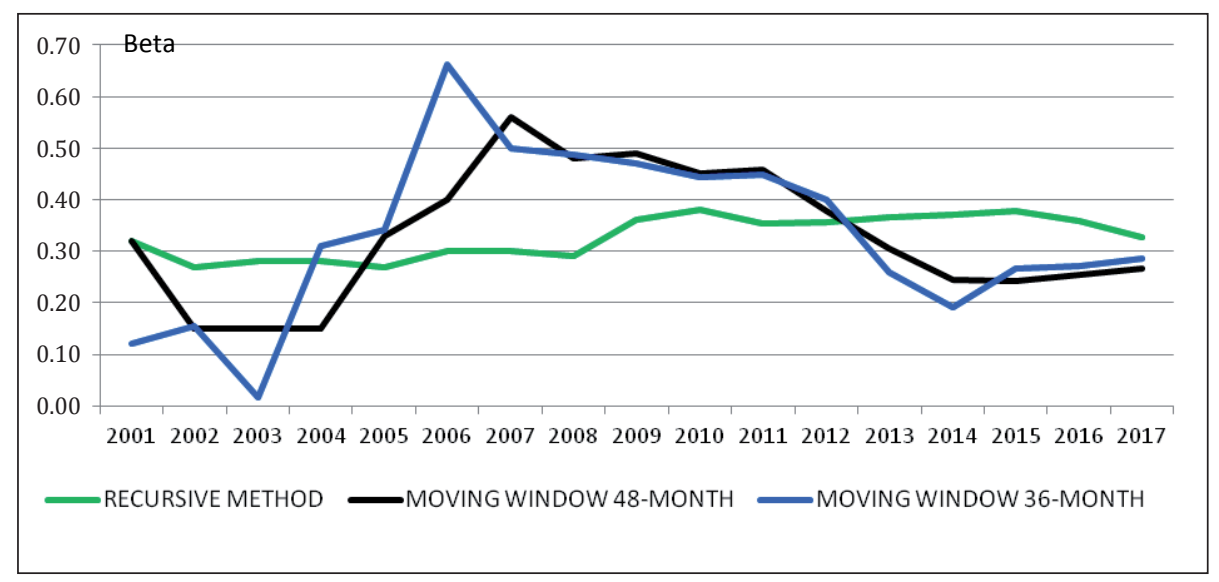

Fig. 1. The $\beta$ parameters for Indykpol S.A. estimated using the recursive method and moving windows method over a period of 48 months and 36 months.

Source: own calculations.

The moving window method of a 36-month time span and less, failed to show stability for the $\beta$ parameters over time. In 2003, an 8-fold decrease of the $\beta$ indicator as observed in Indykpol S.A, after which a 15-fold increase was observed in 2004. Such fluctuations do not allow for adaptation in further research and analysis. The $\beta$ indicators, estimated using this method, differed on average by $138 \%$ to those calculated analogically using the recursive method.

For further research, related to the valuation of the cost of equity, the beta coefficients were calculated using the 48-month moving window method. The basic descriptive statistics, including the division into poultry enterprises and red meat companies, pertaining to the estimated parameters are presented in Table 4. 
Table 4

Basic descriptive statistics of the $\beta$ parameters estimated by using the moving windows method (48-month) for poultry enterprises and red meat companies

\begin{tabular}{lcc}
\hline \multicolumn{1}{c}{ Measure } & Poultry meat enterprises & Red meat companies \\
\hline Average & 0.41 & 1.13 \\
Minimum & 0.14 & 0.44 \\
Maximum & 0.80 & 1.91 \\
Median & 0.39 & 1.07 \\
Standard deviation & 0.19 & 0.26 \\
Coefficient of variation & $47 \%$ & $23 \%$ \\
\hline
\end{tabular}

Source: own calculations.

The average value of the beta parameters for poultry enterprises $(0.41)$ is significantly lower than the average calculated for red meat companies (1.13). In the case of poultry enterprises, the minimum and maximum values of the beta parameters are also lower. In the case of poultry enterprises, there is also a lower standard deviation of the estimated beta parameters, however, the coefficient of variation is higher $(47 \%)$ than the analogue, calculated for red meat companies $(23 \%)$. This indicates a lower stability of the beta parameters over time and higher variation at the level of individual enterprises.

According to the accepted method, the authors of the paper established the cost of equity in companies (under research). The results are presented in Table 5.

The $\beta$ parameters for the companies under investigation in 2001-2017, show a certain regularity. The cost of equity was evidently higher for Gobarto, Tarczyński, Kania, PKM Duda and Sokołów in relation to Indykpol, Pamapol, Drop and Drosed. There is $12.6 \%$ difference in the average cost of equity separating these companies during the entire research time-period. In the case of red meat companies only six times did the cost of equity achieve a value below that of $12.6 \%$, which constitutes approx. $12 \%$ of the analysed cases for these companies. But, the cost of equity for: Indykpol, Drosed, Drop and Pamapol exceeded $12.6 \%$ only once from amongst 44 observations. A similar regularity is noticeable in Table 3 , presenting the $\beta$ indicators estimated by way of the moving windows method with a 48-month time period. Red meat companies (PKM Duda, Gobarto, Tarczyński, Kania and Sokołów) distinguished themselves once again with high values for the $\beta$ coefficient. In the case of these companies, its value frequently exceeded 1.0 ( $71 \%$ observations). For the poultry meat companies, the value of the $\beta$ coefficient failed to exceed 0.8 during the entire time-period.

This evident regularity has its basis. The meat industry as a whole can be generally divided into the processing of poultry and the processing of other meats. The identified regularity results from a number of factors having a fundamental impact on the overall systematic risk of enterprises. This stems from, inter alia, peculiarities of business cycles for various types of livestock. In the case of red meat industry, a longer production cycle of the raw material is observed and a higher depend- 
ence of its price on a wide range of factors: feed prices, current economic situation, weather factors, diseases, variability (sensitivity) of demand. In the case of poultry enterprises, the production cycle is much shorter, enterprises are more vertically integrated, which limits the impact of variability of other factors. In addition, poultry meat enjoys growing recognition from customers, mainly due to its taste and price. On the basis of the investigated companies' financial statements published by EMIS Intelligence, the following Polish business classifications (using the codes from 2007) were observed:

- 10.11 - Sokołów, PKM Duda, Gobarto, Tarczyński, Duda;

- 10.12 - Indykpol, Pamapol, Drosed, Drop.

Table 5

Cost of equity in companies (under research) in 2001-2017 (\%)

\begin{tabular}{lccccccccc}
\hline \multicolumn{1}{c}{ Year } & Indykpol & Duda & Pamapol & Sokołów & Drosed & Gobarto & Drop & Tarczyński & Kania \\
\hline 2001 & 9.30 & $\mathrm{x}$ & $\mathrm{x}$ & 10.44 & 7.58 & $\mathrm{x}$ & $\mathrm{x}$ & $\mathrm{x}$ & $\mathrm{x}$ \\
2002 & 7.51 & $\mathrm{x}$ & $\mathrm{x}$ & 11.28 & 7.39 & $\mathrm{x}$ & $\mathrm{x}$ & $\mathrm{x}$ & $\mathrm{x}$ \\
2003 & 6.75 & 9.06 & $\mathrm{x}$ & 13.69 & 9.25 & 15.83 & $\mathrm{x}$ & $\mathrm{x}$ & $\mathrm{x}$ \\
2004 & 8.05 & 13.41 & $\mathrm{x}$ & 14.18 & 9.95 & 17.44 & $\mathrm{x}$ & $\mathrm{x}$ & $\mathrm{x}$ \\
2005 & 8.37 & 15.24 & $\mathrm{x}$ & 15.03 & $\mathrm{X}$ & 19.81 & $\mathrm{x}$ & $\mathrm{x}$ & $\mathrm{x}$ \\
2006 & 9.51 & 24.94 & 8.56 & 16.79 & $\mathrm{X}$ & 23.30 & $\mathrm{x}$ & $\mathrm{x}$ & $\mathrm{x}$ \\
2007 & 9.98 & 22.16 & 9.84 & $\mathrm{X}$ & $\mathrm{X}$ & 18.27 & 7.85 & $\mathrm{x}$ & $\mathrm{x}$ \\
2008 & 7.42 & 10.15 & 8.11 & $\mathrm{X}$ & $\mathrm{X}$ & 9.21 & 6.63 & $\mathrm{x}$ & $\mathrm{x}$ \\
2009 & 12.01 & 22.19 & 11.40 & $\mathrm{X}$ & $\mathrm{X}$ & 19.64 & 8.78 & $\mathrm{x}$ & 20.34 \\
2010 & 12.03 & 19.73 & 11.27 & $\mathrm{X}$ & $\mathrm{X}$ & 20.27 & 8.45 & $\mathrm{x}$ & 20.36 \\
2011 & 11.08 & 19.14 & 13.57 & $\mathrm{X}$ & $\mathrm{X}$ & 17.81 & 7.63 & $\mathrm{X}$ & 18.09 \\
2012 & 9.37 & 17.78 & 12.05 & $\mathrm{X}$ & $\mathrm{X}$ & 16.41 & 6.93 & $\mathrm{X}$ & 16.83 \\
2013 & 7.48 & 15.86 & 10.83 & $\mathrm{X}$ & $\mathrm{X}$ & 15.99 & 5.81 & 17.07 & 14.94 \\
2014 & 5.98 & 13.36 & 9.36 & $\mathrm{X}$ & $\mathrm{X}$ & 14.30 & 5.85 & 15.68 & 13.27 \\
2015 & 5.59 & 14.96 & 9.84 & $\mathrm{X}$ & $\mathrm{X}$ & 14.92 & 6.50 & 16.21 & 13.48 \\
2016 & 6.05 & 14.72 & 9.85 & $\mathrm{X}$ & $\mathrm{X}$ & 14.23 & 7.22 & 16.61 & 14.42 \\
2017 & 6.19 & $\mathrm{x}$ & 8.78 & $\mathrm{X}$ & $\mathrm{X}$ & 12.10 & 6.38 & 14.76 & 13.50 \\
Average & $\mathbf{8 . 3 9}$ & $\mathbf{1 6 . 6 2}$ & $\mathbf{1 0 . 2 9}$ & $\mathbf{1 3 . 5 7}$ & $\mathbf{8 . 5 4}$ & $\mathbf{1 6 . 6 4}$ & $\mathbf{7 . 0 9}$ & $\mathbf{1 6 . 0 7}$ & $\mathbf{1 6 . 1 4}$ \\
\hline
\end{tabular}

Source: own calculations.

In conclusion it can be stated that companies involved in the processing of poultry incur a lower cost of equity and are characterized by lower $\beta$ coefficient values to companies involved in the processing of other meats (excluding poultry). According to investors, owners and other company capital providers, companies involved in the processing of poultry incur lower business risk than companies involved in the processing of other meats (excluding poultry). This conclusion is an interesting basis for further, deeper operational activity risk analysis into particular meat sub-sectors, using the Hamady and pure play method (Brigham, 1996). 
Upon analyzing all the estimated parameters of the CAPM model, it is worth considering which of them should determine the final size of cost of equity and which should remain neutral. Higher cost of equity should be incurred by companies involved in higher risk, thus a higher $\beta$ coefficient. These values should strongly correlate. The dependency between the $\beta$ coefficient and cost of equity for all companies under investigation is presented in Figure 2.

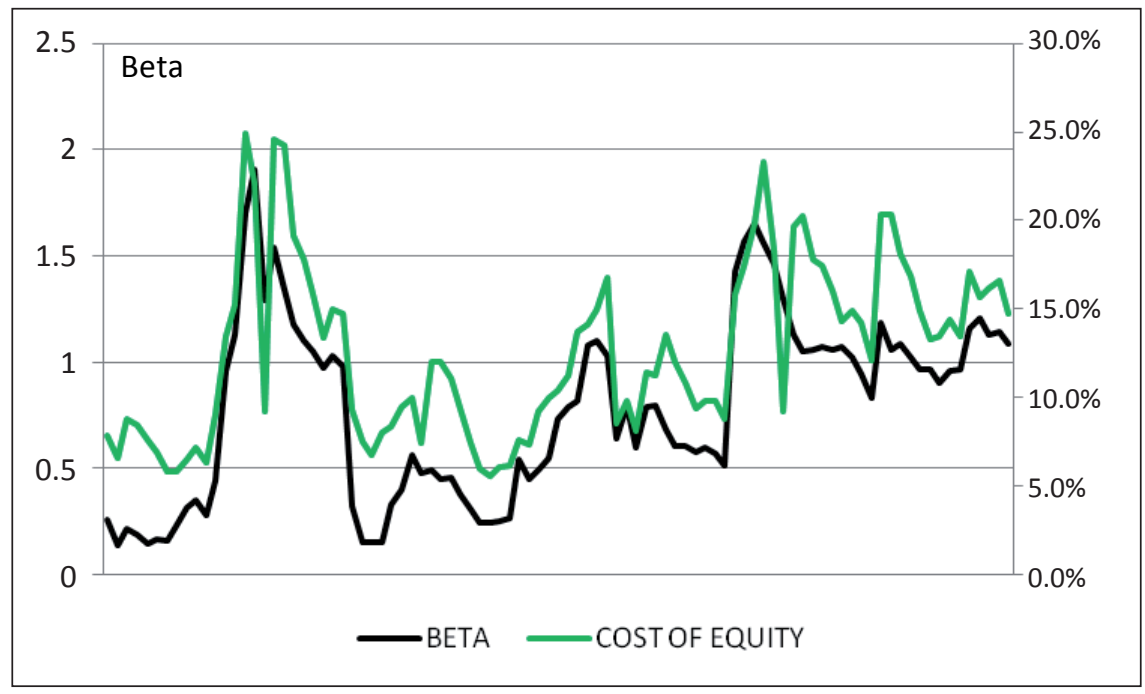

Fig. 2. The $\beta$ coefficient and cost of equity in researched meat sector enterprises. Source: own calculations.

Figure 2 presents a significant dependency between the $\beta$ coefficient and cost of equity. The correlation coefficient amounted to 0.89 , which means that the cost of equity is strongly determined by the size of the $\beta$ coefficient. This conclusion means that the use of the CAPM model was correct for one of the basic assumptions. The greater the risk, the higher the returns expected by the capital provider, which for the receiver of capital - the enterprise - means a higher cost of equity. This conclusion verifies hypothesis H1, which has proved correct. An analysis of the remaining CAPM model parameters indicates a lower value for correlation coefficients in relation to cost of equity, whose module did not exceed 0.32 . This means that the subjectively chosen parameters of the CAPM model, i.e. the risk-free rate and the market rate of return, along with the adopted methodology for their estimation, have no fundamental impact on the final results in terms of the cost of equity.

The cost of foreign capital calculated on the basis of financial statements ranged between $4.12 \%$ and $14.03 \%$. In the case of cost of foreign capital, the previous difference between poultry and other meat processing entities is imperceptible. This time, no characteristic features for these two groups could be found. For cost of foreign capital, no evident directions of change could be found either. An analysis of the reasons for the change in the cost of foreign capital gave rise to the formula- 
tion of hypothesis $\mathrm{H} 2$, indicating a dependency between the cost of foreign capital and the level of interest debt. This regularity failed to be proven for all companies under research (correlation coefficient amounting to 0.28) and respective companies (the correlation coefficient ranged between 0.11 and 0.67 ). Thus, no basis can be found to accept hypothesis H2. Deeper analysis showed a strong correlation between the cost of foreign capital and total share of debt in liabilities. This regularity was not seen in the entire group under investigation (correlation coefficient equaled 0.57 ), but in particular companies this coefficient ranged between 0.67 and 0.89 .

The lack of dependency between cost of foreign capital and total share of liabilities in the entire research sample suggests that an individual assessment is made by providers of (interest) capital in relation to particular companies. Therefore, no defined level of company debt at which capital providers increase its cost, can be distinguished. The assessment is made individually in relation to each of the entities under investigation. However, an evident regularity indicates that the share of debt liability in liability structure (for example bank loans) does not determine the final cost of foreign capital. The providers of interest capital place greater emphasis on total liabilities than interest liabilities. This situation shows that money owned to suppliers, which in the meat industry constitutes a significant share in the structure of liabilities, are not a cost-free source of short-term capital. An indirect cost of a high level of short-term interest-free liabilities (money owned to suppliers, wages and others) is an increase in the cost of interest liabilities.

Knowledge of the cost of equity, cost of foreign capital and share of particular sources of capital in the structure of liabilities enabled the calculation of the weighted average cost of capital (WACC), which is presented in Table 6.

The results presented in Table 6 (analogically to Table 5), show a clearly higher weighted average cost of capital for red meat companies. These companies incurred a weighted average cost of capital of over $13.2 \%$. Companies involved in processing of poultry saw a weighted average cost of capital amounting to 7-8\%, i.e. 5-6 pp lower than in the case of PKM Duda, Gobarto, Tarczyński, Kania or Sokołów. These findings indicate a lack of homogeneity in the specifics of the meat industry, as well as various sources of financing the businesses and their cost.

An analysis of values presented in Tables 5 and 6 reveals a lower level of weight average cost of capital in relation to cost of equity. Total cost of capital decreased in relation to equity due to its dilution with cheaper foreign capital. Additionally, the use of foreign (interest) capital enabled entrepreneurs to adopt the so-called tax shield method, which lowers the final cost of foreign capital. This explanation corresponds with the theory of finances in the scope of cost of capital and is proven in a number of empirical studies. 
Table 6

Weighted average cost of capital for companies under research in 2001-2017 (\%)

\begin{tabular}{|c|c|c|c|c|c|c|c|c|c|}
\hline Year & Indykpol & Duda & Pamapol & Sokołów & Drosed & Gobarto & Drop & Tarczyński & Kania \\
\hline 2001 & 8.46 & $\mathrm{x}$ & $\mathrm{x}$ & 9.15 & 7.25 & $\mathrm{x}$ & $\mathrm{x}$ & $\mathrm{x}$ & $\mathrm{x}$ \\
\hline 2002 & 7.63 & $\mathrm{x}$ & $\mathrm{x}$ & 9.65 & 6.86 & $\mathrm{x}$ & $\mathrm{x}$ & $\mathrm{x}$ & $\mathrm{x}$ \\
\hline 2003 & 7.17 & 7.57 & $\mathrm{x}$ & 11.32 & 7.53 & 13.73 & $\mathrm{x}$ & $\mathrm{x}$ & $\mathrm{x}$ \\
\hline 2004 & 7.34 & 10.24 & $\mathrm{x}$ & 12.09 & 8.43 & 14.47 & $\mathrm{x}$ & $\mathrm{x}$ & $\mathrm{x}$ \\
\hline 2005 & 7.25 & 10.89 & $\mathrm{x}$ & 13.30 & $\mathrm{x}$ & 15.57 & $\mathrm{x}$ & $\mathrm{x}$ & $\mathrm{x}$ \\
\hline 2006 & 7.81 & 15.63 & 7.34 & 14.86 & $\mathrm{x}$ & 17.16 & $\mathrm{x}$ & $\mathrm{x}$ & $\mathrm{x}$ \\
\hline 2007 & 8.23 & 15.86 & 8.05 & $\mathrm{x}$ & $\mathrm{x}$ & 15.16 & 7.30 & $\mathrm{x}$ & $\mathrm{x}$ \\
\hline 2008 & 5.89 & 7.85 & 6.97 & $\mathrm{x}$ & $\mathrm{x}$ & 10.58 & 6.67 & $\mathrm{x}$ & $\mathrm{x}$ \\
\hline 2009 & 8.01 & 14.26 & 9.76 & $\mathrm{x}$ & $\mathrm{x}$ & 15.30 & 8.36 & $\mathrm{x}$ & 18.53 \\
\hline 2010 & 8.40 & 13.98 & 9.68 & $\mathrm{x}$ & $\mathrm{x}$ & 15.95 & 8.07 & $\mathrm{x}$ & 18.09 \\
\hline 2011 & 9.86 & 15.66 & 10.55 & $\mathrm{x}$ & $\mathrm{x}$ & 14.46 & 7.64 & $\mathrm{X}$ & 13.44 \\
\hline 2012 & 9.14 & 14.72 & 9.63 & $\mathrm{x}$ & $\mathrm{x}$ & 14.29 & 6.91 & $\mathrm{X}$ & 12.95 \\
\hline 2013 & 8.29 & 14.39 & 9.00 & $\mathrm{x}$ & $\mathrm{x}$ & 13.60 & 5.88 & 13.85 & 12.31 \\
\hline 2014 & 7.43 & 13.70 & 8.18 & $\mathrm{x}$ & $\mathrm{x}$ & 12.71 & 5.91 & 13.52 & 11.72 \\
\hline 2015 & 7.28 & 13.49 & 8.52 & $\mathrm{x}$ & $\mathrm{x}$ & 13.07 & 6.38 & 13.58 & 11.78 \\
\hline 2016 & 8.17 & 12.96 & 8.46 & $\mathrm{x}$ & $\mathrm{x}$ & 12.74 & 8.57 & 13.67 & 12.27 \\
\hline 2017 & 8.22 & $\mathrm{x}$ & 7.83 & $\mathrm{x}$ & $\mathrm{x}$ & 12.17 & 8.50 & 12.86 & 12.19 \\
\hline Average & 7.92 & 12.94 & 8.66 & 11.73 & 7.52 & 14.06 & 7.29 & 13.50 & 13.70 \\
\hline
\end{tabular}

Source: own calculations.

\section{Conclusions}

The research reveals that (owner) equity is a more expensive source of financing in the companies under research, than foreign capital. Moreover, the final cost of foreign capital is subject to a decrease due to the possibility of including costs of interest in tax deductible expenses, enabling the use of the tax shield mechanism.

The research carried out in accordance with the adopted methodology has proved that the proposed mechanism for estimating the cost of capital is appropriate. It was confirmed that the final result of the level of the cost of equity depends on the level of the $\beta$ index, and thus depends on the level of risk characterizing the given enterprise. The remaining parameters of the CAPM model did not distort the final results. The hypothesis $\mathrm{H} 1$ was confirmed. The obtained results do not differ significantly from global results (Zarzecki and Byrka-Kita, 2005).

The hypothesis $\mathrm{H} 2$ was verified as a result of the research. It was not possible to prove that the cost of foreign capital increases with the share of interest liabilities in the structure of liabilities. In addition, it was found that the cost of foreign capital depends on the total share of liabilities in the structure of liabilities (including 
non-interest liabilities). Therefore, not only the share of interest liabilities determines the cost of foreign capital, but above all the sum of liabilities. In this type of research, it is necessary to take into account the individual approach of capital providers to specific entities. The dependence proposed by the authors has been confirmed separately for each unit from the research sample. The research allowed identification of characteristics of two subgroups of the meat industry:

- Poultry processing - characterized by lower $\beta$ coefficients in relation to medium size, low cost of equity, lower average weighted cost of capital;

- Meat processing (without poultry) - was characterized by a higher level of the $\beta$ in relation to the sector average, higher cost of equity, higher average weighted cost of capital.

The presented observations indicate the lack of uniformity in the specificity of the meat industry. Therefore, there is a need for further analysis in both proposed sub-segments of the meat sector.

Certain problems pointing to the CAPM limitations and imperfections remain unresolved and require further multidimensional research.

\section{Limitations:}

- In the case of negative cost of equity, there is a dilemma concerning its logical interpretation. Assuming that the calculated value is the rate of return from invested capital, this explanation is logical. However, the assumption that this value is the cost of capital brings with it certain difficulties.

- The dilemma concerning the valuation of equity in cases when company equity is negative due to unsettled losses remains unsolved.

\section{Findings of the research}

In our assessment one should:

- Recommend calculating the cost of equity and include it in the balance of business efficiency - to enable a real assessment of invested capital efficiency.

- Recommend an individual approach to the cost of equity. One should not automatically use proposed solutions found in scientific literature. The specifics of each sector, branch and even respective entities (in our view) determine the level of the cost of capital.

- In the case of a model approach to estimating the cost of equity, we recommend including additional risk factors - both those resulting from improved versions of the simple CAPM, as well as other factors specific to the different branches of the industry.

- Recommend paying attention to the fact that despite a seeming dependency between interest liabilities and the whole cost of liabilities, this dependency is not directly proportional.

- Recommend further research into the assessment of the cost of equity, its influence on the decisions concerning sources of financing business operations, acknowledging the specifics of entities. 


\section{References}

Acharya, V.V., Shin, H.S., Yorulmazer, T. (2013). A theory of Arbitrage capital, The Review of Corporate Finance Studies. Vol. 2, No. 1, pp. 62-97.

Arouri, M.E.H., Rault, C., Sova, A., Sova, R., Teulon, F. (2013). Market structure and the cost of capital, Economic Modelling. Vol. 31, pp. 664-671.

Augustyńska-Prejsnar, A., Sokołowicz, Z. (2014). Czynniki kształtujące jakość sensoryczną mięsa kurcząt brojlerów. Wiadomości Zootechniczne, No. 2(52), pp. 108-116.

Bartholdy,J.,Peare,P.(2003). Unbiased estimation of expected return using CAPM.International Review of Financial Analysis, No. 12, p. 70.

Black, F., Jensen, M.C., Scholes, M. (1972). The Capital Asset Pricing Model: Some Empirical Tests, Studies in the Theory of Capital Markets. New York: M.C. Jensen, Preager.

Boratyńska, K. (2009). Koszty bankructwa przedsiębiorstwa na świecie i w Polsce - przegląd dotychczasowych badań. Zeszyty Naukowe SGGW, Ekonomika i Organizacja Gospodarki Żywnościowej, No. 78, pp. 175-186.

Boratyńska, K. (2012). Predicting Bankruptcy of Selected Companies from The Polish Meat Sector. Economic Science for Rural Development, No. 28, pp. 170-175.

Boubakri, N., Guedhami, O., Mishra, D., Saffar, W. (2012). Political connections and the cost of equity capital. Journal of Corporate Finance, vol. 18, pp. 541-559.

Brigham, E. (1996). Podstawy zarzadzania finansami. T. 2. Warszawa: PWE.

Brown, S.J., Lajbcygier, P., Wong, W.W. (2012). Estimating the cost of capital with basis assets. Journal of Banking \& Finance, vol. 36, pp. 3071-3079.

Byrka-Kita, K. (2008). Metody szacowania kosztu kapitału własnego, Teoria a praktyka. Szczecin: Wydawnictwo Naukowe Uniwersytetu Szczecińskiego.

Chen,Z., Harford, J., Kamara, A. (2013). Operating inflexitability and capital structure. $40^{\text {th }}$ Anuual Meeting European Finance Association, Cambridge.

Cukiernik, T. (2008). Byliśmy dwa razy bogatsi niż Niemcy. Najwyższy Czas, No. 31-32, Wydawnictwo internetowe.

Da, Y., Guo, R.J., Jagannathan, R. (2012). CAPM for estimating the cost of equity capital: Interpreting the empirical evidence. Journal of Financial Economics, vol. 103, pp. 204-220.

Damodaran, A. (1994). Damodaran on Valuation, Security Analysis for Investment and Corporate Finance. New York: John Wiley \& Sons.

Douglas, G. (1968). Risk in the Equity Markets: An Empirical Appraisal of Market Efficiency. Michigan: University Microfilms Inc., Ann Arbor.

Drewnowska, B. (2010). Widmo upadłości wisi nad rynkiem mięsnym. Parkiet, 03 .02.2010 r., Retrieved from: http://www.parkiet.com/artykul/894003.html (access date: 01.06.2011).

Duliniec, A. (2001). Struktura i koszt kapitału w przedsiębiorstwie. Warszawa: Wydawnictwo Naukowe PWN.

Fama, E., MacBeth, J. (1973). Risk, Return, and Equilibrium: Empirical Tests. Journal of Political Economy, May-June, pp. 607-636.

Farhurst, D. (2013). Financing seasonal Demand and capital structure choice. $40^{\text {th }}$ Anuual Meeting European Finance Association, Cambridge.

Fierla, A. (2008). Wycena przedsiębiorstwa metodami dochodowymi. Warszawa: SGH.

Franc, J. (2003). Struktura kapitału a procesy rozwojowe przedsiębiorstw rolniczych. Warszawa: Wydawnictwo SGGW.

Franc-Dąbrowska, J. (2009), Does dividend policy follow the theory of the capital structure? Managing Global Transitions, vol. 7, No. 4, pp. 367-382. 
Franc-Dąbrowska, J.(2010). Teoretyczne i praktyczne aspekty gospodarowania zyskiem w przedsiębiorstwach rolniczych. Rozprawy Naukowe i Monografie, No.365. Warszawa: Wydawnictwo SGGW.

Franc-Dąbrowska, J., Kobus, P. (2012). Koszt kapitału własnego - dylematy wyceny. Zagadnienia Ekonomiki Rolnej, No. 1(330), pp. 77-89.

Górnicka, A. (2005). Tradycyjnie a nowocześnie. Cool Biznes, No. 6, p. 22.

Grzywacz,J.(2012). Kapitał w przedsiębiorstwie i jego struktura. Warszawa: Oficyna Wydawnicza Szkoły Głównej Handlowej w Warszawie.

Hüttel, S., Mußhoff, O., Odening, M. (2010). Investment reluctance: irreversibility or imperfect capital markets?. European Review of Agricultural Economics, vol. 37, No. 1, pp. 51-76.

International Markets Bureau (2012). Market Indicator Report, March 2012, Processed Meats in the United States, Ottawa.

Jajuga, K., Jajuga, T. (1994). Jak inwestować w papiery wartościowe. Warszawa: Wydawnictwo Naukowe PWN.

Kalwasińska, M. (2011). Przetwórcy wieprzowiny skarża się na coraz niższa rentowność. 11.08.2011. Retrieved from: http://www.portalspozywczy.pl/mieso/wiadomosci/przetworcywieprzowiny-skarza-sie-na-coraz-nizsza-rentownosc,55350.html (access date: 23.10.2011).

Knap-Stefaniuk, A. (2010). Polska branża mięsna.Cz. I, Analiza wybranych zagadnień. Retrieved from: http://www.wsz-pou.edu.pl/biuletyn/druk.php?p=\&stronabiul_miesoknap1\&nr=39 (access date: 12.11.2010).

Kolb, R. (1995). Theory Succession, the CAPM, and the APT. The Corporate Finance Reader, Blackwell, USA.

Kowalski, J. (2011). Analiza branżowa - Branża mięsna i drobiarska, EKD 15.1. Retrieved from: http://www.portal-bankrut.pl/branze/mieso.pdf (access date: 25.10.2011).

Kulawik, J. (ed.). (2008). Analiza efektywności ekonomicznej i finansowej przedsiębiorstw rolnych powstałych na bazie majątku WRSP. Warszawa: IERiGŻ-PIB.

Kuziak, K. (1999). Stabilność w czasie współczynnika beta akcji. Prace Naukowe Akademii Ekonomicznej we Wrocławiu, No. 811, pp. 62-69.

Laderman, L.M. (1988). What Does Equity Financing Really Cost?. Business Week, December 7 , p. 147.

Lagerkvist, C.J. (1999). The user cost of capital in Danish and Swedish agriculture. European Review of Agricultural Economics, vol. 26, No. 1, pp. 79-100.

Łącka, I. (2012). Integracja pionowa w przetwórstwie drobiu szansą na wzrost i rozwój firmy we współczesnej gospodarce (na przykładzie GK Indykpol SA). Roczniki Ekonomii Rolnictwa i Rozwoju Obszarów Wiejskich, No. 99(2), pp. 94-102.

Łukasik, G. (1998). Polityka pozyskiwania kapitału przez przedsiębiorstwa w warunkach rozwoju rynku finansowego. Katowice: Akademia Ekonomiczna.

Masulis, T.W. (1988). The Debt/Equity Choice. Cambridge: Ballinger Publishing Company.

Milan, M. (2017). Rynek mięsny w natarciu. Gazeta Finansowa - Biznes Raport, Rynek mięsa w Polsce, No. 24-30, November, pp. 28-29.

Miller, R.A. (2009). The weighted average cost of capital is not quite right. The Quarterly Review of Economics and Finance, vol. 49, pp. 128-138.

Modigliani, F., Miller, M.H. (1958). The cost of capital, corporation finance and the theory of investment. The American Economic Review, vol. 18, No. 3, pp. 261-297.

Modigliani, F., Miller, M.H. (1963). Corporate Income Taxes and the Cost of Capital: A Correction. The American Economic Review, vol. 53, No. 3, pp. 433-443. 
Myers, S.C., Majluf, N.S. (1984). Corporate Financing and Investment Decisions When Firms Have Information That Investor Do Not Have. Journal of Financial Economics, vol. 13, issue 3, pp. 187-221.

Obidzińska, E. (2008). Mglista przyszłość branży mięsnej. Fresh\&Cool Market, No. 10/08, listopad, pp. 10-12.

Osińska, M., Stempińska, J. (2003). Zmienność parametru $\beta$ w modelu Sharpe'a a horyzont czasowy inwestycji. Nasz Rynek Kapitałowy, No. 9(153), September, pp. 129-136.

Patena, W. (2011). W poszukiwaniu wartości przedsiębiorstwa. Warszawa: Wolters Kluwer.

Pereiro, L.E. (2010), The Beta Dilemma in Emerging Markets. Journal of Applied Corporate Finance, vol. 22, issue 4, pp. 110-122.

Pluta, W. (2009). Zarządzanie wartością w małych i średnich przedsiębiorstwach. Warszawa: PWE.

Ranking 300 najlepszych przedsiębiorstw rolnych w 2011 (2012). Warszawa: IERiGŻ-PIB, Agencja Nieruchomości Rolnych. Retrieved from: http://www.ierigz.waw.pl/publikacje/poza-seria/1361368486 (access date: 13.03.2012).

Rawa, Ł. (2009). Nadchodzi rok prawdy dla branży mięsnej. Rynek Spożywczy. Retrieved from: http://www.bankier.pl/wiadomosc/Nadchodzi-rok-prawdy-dla-branzy-miesnej-1930478. html (access date: 13.11.2010).

Rawa, Ł. (2017). Nadchodza duże zmiany w branży mięsnej. Rozmowa z Renatą Dutkiewicz, dyrektor ds. sektora spożywczego w Banku Zachodnim WBK. Retrieved from: https://www. wiadomoscihandlowe.pl/artykuly/nadchodza-duze-zmiany-w-branzy-miesnej-wywiad-zdy,39874 (access date: 10.05.2017).

Ross, S., Westerfield, R., Jordan, B. (2008). Corporate Finance. SOAS, University of London.

Sadowska, A., Rakowska, R., Dybkowska, E., Świąder, K. (2016). Czynniki przedubojowe warunkujące wartość odżywczą i jakość sensoryczną mięsa wołowego. Postepy Techniki Przetwórstwa Spożywczego, No. 2, pp. 122-128.

Sharpe, W.F., Cooper, G.M. (1972). Risk-Return Class of New York Stock Exchange Common Stocks, 1928-1969. Financial Analysts Journal, No. 2, March-April, pp. 46-52.

Sroka, P. (2010). Czas Akcji, ZM Duda. Retrieved from: pkmduda.pl/pub/File/prezentacja/2002/ 2002_ipo.pdf (access date: 27.10.2013).

Stiglitz, J.E. (1974). On the Irrelevance of Corporate Financial Policy. The American Economic Review, vol. 64, No. 6, pp. 851-866.

Wieczorkiewicz, R. (2008). Jak rozwija się branża mięsna, Rynek Spożywczy. Retrieved from: http://www.bankier.pl/wiadomosc/Jak-rozwija-sie-branza-miesna-1724859.html (access date: 12.11.2010).

Zarzecki, D., Byrka-Kita, K. (2005). O pewnej metodzie szacowania kapitału własnego na rynkach wschodzących. In: M. Hamrol (ed.), Analiza finansowa jako narzędzie zarzadzania przedsiębiorstwem (pp. 326-327). Poznań: Akademia Ekonomiczna.

Zawadzka, D. (2009). Znaczenie zobowiązań krótkoterminowych w finansowaniu przedsiębiorstw w Polsce - analiza porównawcza według sekcji PKD. Zeszyty Naukowe SGGW, Ekonomika i Organizacja Gospodarki Żywnościowej, No. 76, pp. 85-94. 


\title{
KOSZT KAPITAŁU I STRUKTURA KAPITAŁOWA PRZEDSIĘBIORSTW BRANŻY MIĘSNEJ NOTOWANYCH NA GIEŁDZIE PAPIERÓW WARTOŚCIOWYCH W WARSZAWIE - DYSKUSJA NA TEMAT PROBLEMU WYCENY
}

\begin{abstract}
Abstrakt
Koszt kapitału to ważny parametr w ocenie skuteczności wykorzystania źródet finansowania przedsiębiorstw. Jest to również miara pozwalajaca na dokonanie pośredniej weryfikacji podstawowego celu długofalowej działalności przedsiębiorstwa - wzrostu wartości. Jak dotąd nie opracowano w pełni przejrzystego modelu oceny kosztów kapitału zarówno w teorii, jak i praktyce. W rezultacie szacunki dotyczace kosztu kapitału i wartości spółek sq $w$ dużym stopniu subiektywne. Przeprowadzone badania - z wykorzystaniem modelu CAPM wraz z przyjętymi parametrami - świadczq o stabilności i precyzji zastosowanej metodologii. Szacowanie kosztów kapitału ma szczególne znaczenie w przedsiębiorstwach polskiego przemystu miesnego. Podmioty te (w latach objetych badaniem) byty zobowiazane do zwiększenia nakładów inwestycyjnych z powodu przystapienia Polski do Unii Europejskiej oraz konieczności dostosowania się do norm zachodnioeuropejskich i dalszej konsolidacji zarówno $w$ wymiarze pionowym, jak i poziomym. Działania prorozwojowe wymagały zmian źródeł finansowania, a co za tym idzie - zmian w strukturze kapitału. Dylemat dotyczacy „, bezpieczniejszego”, ale droższego kapitału (właściciela) czy „tańszego”, ale mniej stabilnego kapitału zagranicznego (odsetkowego), pozostaje nierozwiazany do dnia dzisiejszego.
\end{abstract}

Słowa kluczowe: koszt kapitału, finanse, przedsiębiorstwa rolnicze.

Accepted for print: 18.12.2018.

Unless stated otherwise all the materials on the website are available under the Creative Commons Attribution 4.0 International license.

Some rights reserved to the Institute of Agricultural and Food Economics - National Research Institute.

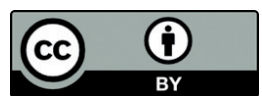

